\title{
类
}

\section{Reconciliation: The South African Truth and Reconciliation Commission's contribution to dealing with the past, reconciling and building the nation}

\author{
S. Barry \\ School of Ecclesiastical Science \\ North-West University \\ POTCHEFSTROOM \\ E-mail: 3rmethodist@telkomsa.net
}

\begin{abstract}
Reconciliation: The South African Truth and Reconciliation Commission's contribution to dealing with the past, reconciling and building the nation
\end{abstract}

International experience has shown that addressing past human rights violations is a necessary step in the process of reconciliation and nation building. How was post-apartheid, democratic South Africa to deal with its past human rights violations? Would it go the way of retribution in order to settle the scores of the past? Would it go the way of blanket amnesty in the name of political expediency and ignore the fate of its victims?

The Promotion of National Unity and Reconciliation, Act 34 of 1995, which established the TRC envisaged that national unity and reconciliation could be promoted by determining the extent, and the fate and whereabouts of the victims, of such human rights violations; giving opportunity for story-telling; recommending reparations and measures to prevent future violations; and by providing a full report. In order to do so the Commission had the power to grant amnesty to those making such disclosures.

This article, while not uncritical of the Commission, is generally positive about its contribution both in attempting to deal with the past, and in building a democratic, human rights and restorative justice culture based on the rule of law. It examines the definitions of reconciliation that emerged during the Commission in the light of a Christian definition where 
reconciliation is seen to be between God, others and self, and involves integration with the human community. This integration involves taking responsibility for the past, confession and repentance, forgiving and being forgiven, making restitution where possible, ongoing transformation in the present and hope for the future.

\section{Opsomming}

\section{Rekonsiliasie: Die Suid-Afrikaanse Waarheids- en Versoenings- kommissie se bydrae tot die hantering van die verlede, rekonsiliasie en nasiewording}

Internasionale ondervinding toon dat 'n noodsaaklike stap in die proses van rekonsiliasie en nasiewording die hantering van menseregteskendings uit die verlede is. Hoe moes postapartheid demokratiese Suid Afrika sy mensgeregteskendings uit die verlede hanteer? Moes dit die pad van vergelding volg om sodoende die ongeregtighede van vroeër gelyk te stel, of moes dit die pad van allesdekkende amnestie volg ter wille van politiese prosesversnelling en sodoende die noodlot van die slagoffers ignoreer?

Die Promosie van Nasionale Eenheid en Rekonsiliasie, Wet 34 van 1995, verantwoordelik vir die daarstelling van die WVK, het as oogmerk: die daarstelling van 'n platform vir slagoffers se storie om gehoor te word; die aanbeveling van herstellende vergoeding en maatreëls om 'n herhaling van soortgelyke oortredings te voorkom; en die samestelling van 'n volledige verslag. Om dit te bewerkstellig, is die WVK gemagtig om amnestie te verleen aan diegene wat tersaaklike openbarings sou maak.

Hierdie artikel, alhoewel nie onkrities teenoor die WVK nie, is oorwegend positief ten opsigte van die bydraes synde pogings om die verlede te hanteer, en ook die daarstelling van 'n demokratiese, menseregte- en herstellende wetgewing gebaseerde oriëntasie, met fondasies in die gemene reg. Die artikel ondersoek die definisies van rekonsiliasie, soos voortgebring deur die WVK, in die lig van 'n Christelike definisie, waar rekonsiliasie gesien word as 'n versoening tussen God, andere en die self, met 'n element van integrasie met die menslike gemeenskap. Hierdie integrasie sluit in die aanvaarding van verantwoordelikheid, erkenning van skuld, berou, die ontvang en verlening van vergifnis, herstellende vergoeding waar moontlik, voortdurende transformasie in die hede en hoop vir die toekoms. 


\section{Introduction}

It is important to remind us all that the TRC is expected to promote, not to achieve reconciliation

(Desmond Tutu).

As the South African Truth and Reconciliation Commission (TRC) drew to its close, the chairperson, Archbishop Desmond Tutu (1998:6) felt it necessary

... to remind us all that the TRC is expected to promote, not to achieve, reconciliation. Reconciliation has to be the responsibility of all South Africans, a national project - and we hope that the churches and other faith communities will be in the forefront of this healing process which is possibly going to go on for decades. We have all been deeply wounded and traumatized and it will take long to undo centuries of the alienation and animosity that were deliberate state policy.

The Truth and Reconciliation Commission was created by the Promotion of National Unity and Reconciliation, Act 34 of 1995. During its tenure, and since it presented its report to the nation at the end of October 1998, the TRC has generated much discussion, debate and criticism - both constructive and negative - not to mention much academic research and publication. From many perspectives - among them, the legal, the ethical and that of mental health professionals - many questions have been asked, and many different answers have been given about the TRC:

- Did it present the truth?

- Did it promote reconciliation?

- Did it sacrifice truth for political expediency?

- Did it sacrifice justice for indemnity?

- Did it sacrifice the needs of individuals for the need to legitimise the post-apartheid state?

- Did it bind up, or merely open up, the wounds of the past? Did it fulfil its mandate?

- Did it raise more questions than it answered?

It is not the intention here to revisit these questions and the differing and conflicting answers given to them, as it is to ask the question: What was the TRC's contribution to dealing with the past, reconciling and building the nation? 
Nevertheless, in attempting to answer that question, it is necessary to look at the Act in its title, objective and powers to promote "national unity and reconciliation" (Section 3(1)) and establish truth.

\section{Reconciliation: dealing with the past}

How do we deal with the past? One South African response was to grant blanket amnesty (let's forgive, forget and move on); while another, within the ANC, in the words of Thabo Mbeki in an interview in the Cape Times (24 February 1997) was "to catch the bastards and hang them". Fortunately there was a realisation that this route, that of Nuremburg-style trials for the members of the apartheid state security establishment, would never have facilitated a peaceful transition (Boraine, 2000:13-14).

International experience has shown that addressing past human rights violations is a necessary step in the process of reconciliation and nation-building. The purpose of such action, often at the moment of political change, is to demonstrate a break with the past, promote national reconciliation, and to obtain or sustain political legitimacy.

The TRC was but one of a series of such commissions held in different parts of the world since the mid-1970s. One example was the 1991 Chilean Commission on Truth and Reconciliation. Israel, Guinea, Uganda and Argentina have also established their commissions; likewise Chad, El Salvador, Honduras, Sri Lanka and Thailand - all have met with limited success.

Instead of a truth and reconciliation commission, Eastern Block countries set up procedures to investigate files of former regimes, a process known as lustration, with the Czech Republic carrying it out the most. The problems with this procedure include the following: facts concerning the missing and the dead were not recovered; no justice was rendered to perpetrators; and victims and families felt cheated by the compromises made without their consent. The outcome of these procedures tended to be: No truth! No justice! No reconciliation!

The lustration process can be further compounded by the alteration of files, and by innocent people being condemned unjustly.

In South Africa there were forerunners to the TRC. The Goldstone Commission of Enquiry identified death squad activities within the police force in KwaZulu Natal. The ANC also set up a number of 
internal commissions to deal with allegations of human rights abuses committed by ANC cadres, yet the verification of such allegations did not lead to discipline or removal from leadership another example of truth not leading to justice!

Two conferences were held in Cape Town in 1994. The first held in February recorded its proceedings in Dealing with the past. The second was held in July, but many political organisations did not send delegates as there was widespread opposition to a truth commission. The healing of a nation? (1995) published the papers presented, including that of the keynote speaker, the Minister of Justice, Dullah Omar, who had earlier announced to Parliament (27 May 1994) the government's decision to set up a commission of truth and reconciliation. The stated purpose of the Promotion of National Unity and Reconciliation, Act 34 of 1995 was:

to bring about unity and reconciliation by providing for the investigation and full disclosure of gross violation of human rights committed in the past. It is based on the principle that reconciliation depends on forgiveness and that forgiveness can only take place if gross violations of human rights are fully disclosed (Hay, 1998:53).

The Act was in many ways the result of political manoeuvring, a compromise which resulted from the negotiation process at Kempton Park, it being in the interests of both the regime and the ANC to provide amnesty for themselves. Nevertheless, Dullah Omar emphasised that reconciliation would not simply be a question of indemnity through amnesty. He stressed that "to ignore the sufferings of countless victims" by "merely granting amnesty to perpetrators without addressing our international obligations, dealing with the wounds of the past, and our duty to victims, will undermine the process of reconciliation. It is necessary, therefore, to deal with South Africa's past, including amnesty, on a morally acceptable basis" (Boraine, 2000:68).

President Nelson Mandela appointed Archbishop Desmond Tutu and Alex Boraine as the chairperson and deputy chairperson respectively, of the Commission. It held its first meeting on South Africa's Day of Reconciliation, 16 December 1995. This day is significant for various reasons: on that day many Afrikaners celebrate the Day of the Covenant, the defeat of 12000 Zulus in 1838; on that day too, the ANC began its armed struggle in 1961. 


\section{- What was the TRC and what was its mandate?}

Omar emphasised that the Commission would not be a court of law and would not conduct trials; neither would it affect the role of the criminal justice system. Its object, he stated, was "to facilitate the healing of our deeply divided society on a morally acceptable basis ... not a witch hunt, but ... based on the need to restore a national moral conscience ... a society based on respect for human rights and human dignity" (Boraine, 2000:71).

Desmond Tutu (1998:4-5) described the TRC as

part of the tender bridge from a repressive past filled with conflict to a new dispensation with a healed and reconciled nation which has come to terms with its past, not by amnesia or trials, but by amnesty and storytelling. It is a commission seeking to establish as much of the truth about a specific segment of the past (1960-1994) as needed to provide as complete a picture as possible of gross human rights violations arising from the conflict of the past.

The Act envisaged that the TRC would "promote national unity and reconciliation" in a spirit of understanding, by establishing the truth and disseminating its findings.

The Commission was therefore to investigate the nature, causes and extent of gross human rights violations committed in South Africa from 1 March 1960 to 10 May 1994. It was mandated to determine the fate or whereabouts of the victims of such violations; give victims opportunities to tell their stories; recommend reparation measures in respect of them; and compile a report and make recommendations of measures to prevent future violations.

The TRC had the power to grant amnesty to those making such disclosures. The ANC applied for an interdict to prevent the publication of certain sections of the report, but the application was dismissed with costs on 29 October 1998, the day the Report was presented to President Mandela.

In order to achieve its objectives, the TRC formed three committees, each with its own primary objective. These were:

- The Committee on Human Rights Violations, which was to investigate the nature, causes and extent of human rights violations; 
- The Committee on Amnesty, which was to consider applications by those who had made a full disclosure and met the criteria in the Act; and

- The Committee on Reparation and Reconciliation, which was to make recommendations for reparations defined in Section 1, as "compensation, ex gratia payment, restitution, rehabilitation or recognition".

Mark Hay (1998:59) refers to the Commission as "but one mechanism, albeit an important one" that began the process of national reconciliation by closing the door to the past. "The closure to the past is important, so long as the procedure of closing ... has been comprehensive and effective."

How "comprehensive and effective" the Commission was in achieving "closure to the past" will no doubt continue to be debated, but in this article the concern is with the TRC's contribution to dealing with the past, reconciling and building the nation.

\section{Reconciliation: attempting to heal the nation}

\subsection{The TRC: a mirror of who we are, and the promise of who we can become.}

Firstly, the TRC presented itself as a microcosm of the nation and as such it could said to hold out a mirror of who we, the rainbow nation are, and a promise of who we, the rainbow nation, can become.

Alex Boraine (2000:441-442) is surely right when he concludes his narrative on the TRC by saying that "despite the suspicion, distrust, and racism experienced within the Commission itself", and its difficulties in being reconciled, "it did not succumb to these negative forces", and therefore holds out the hope that "South Africans, despite our differences and distrust of each other, despite incipient racism, can rise above these problems in order to work together in our common pursuit for a new vision and a new society".

\subsection{The TRC: an exposition of truth}

The TRC exposed a great deal about the nature and extent of gross human rights violations committed in South Africa from 1 March 1960-10 May 1994. It also exposed truth about the causes, motives and perspectives of those responsible, and "the extent to which many ... were themselves victims of a political system and cultural milieu that promoted violence" (Villa-Vincencio, 2000a:204). 
Again it exposed "the capacity of apparently decent people to sink to such a level where they can commit the most atrocious evil" (VillaVincencio, 2000a:203). The TRC reinforced the truth for the necessity of political solutions to prevent further atrocities. It reinforced the truth that information about the past, while not always enough to start the healing process, constitutes a turning point for some (many?), and in the words of Babu Ayindo (writing on the International Criminal Tribunal for Rwanda), "suggests that truth telling is at the heart of most African traditional justice systems that aim to reintegrate both the offender and the victim back into society" (Villa-Vincencio, 2000a:202). Certainly South Africans will never again be able to say "we did not know".

The TRC created a space which did not exist before, where narratives of suffering could emerge, thus allowing greater understanding between the sections of South African society separated by the racialised boundaries of apartheid. Richard A. Wilson (2001:22425), not generally positive about the Commission's effect, wrote that the sharing of narratives of suffering "made possible a greater fusion of horizons, a base-line of understanding," and a definition of the parameters of discussion of the past thus the "range of permissible lies is now much narrower because of the work of the TRC" (italicising added - SB).

The TRC also reported on "the causes, motives and perspectives" of those responsible - albeit with a set of disclaimers arguing that its findings were incomplete and premature since the amnesty hearings were still underway and not all categories of perpetrators had applied for amnesty.

Concerning an understanding of perpetrators, the TRC set out three primary political contexts namely: The Cold War, including the role of the super powers and the virulent strand of anti-communism that took root in white South Africa from the 1950s onwards; anti-colonial struggles across the African continent, which escalated after the Second World War; and apartheid and the liberation struggle, which turned to armed struggle in 1960 following the banning of the ANC and PAC (Foster, 2000:222). Four sets of interrelated factors were set out as explanation, namely authoritarianism, social identities, particular situations and ideological language, and two additional, but traditionally neglected factors, were proposed, namely, special organisational forces and secrecy and silence. Don Foster (2000:224) suggests that in "explanations of atrocities one particular form of social identity - masculinity - has frequently been ignored". 
As in Nazi Germany, it was clear that only a limited number of people were actively involved as perpetrators, the majority of people were not directly involved. However, the relative silence of the many - the media, the state, the general populace and even religious bodies - made the work of the few possible and effective.

The Commission has "reminded us too, that the complexity of perpetration extends beyond those who pull the trigger"; that we should never lose sight of what Hannah Arendt calls the banality of evil, or of what Michel Foucault calls fascism within, that is, the human potential to love power, to desire the very thing which dominates and exploits us; and that "society needs to take responsibility for those it spawns and nurtures (whether those who support, or those who seek to overthrow the system) if it is to redress the forces that contribute to the violation of fundamental human rights" (Villa-Vincencio, 2000a:203-204).

Finally, the TRC raised the question about the prevention of further atrocities. "If perpetrators' actions are primarily political (not biological or psychological) in governance, then prevention will necessitate political solutions - chiefly a fully participative, open, accountable democratic form" (Foster, 2000:228).

\subsection{The TRC: a facilitator of catharsis}

That the TRC facilitated catharsis - indeed reconciliation and healing - for some, but not for all, is probably to be expected and not surprising.

Wilson (2001:121) quotes Brandon Hamber, a psychologist who worked closely with the Commission, given in a personal interview (30 September 1996):

The word catharsis gets used too often within the TRC. There is a perception that as long as a person is crying then healing must be taking place. But crying is only the first step and the lack of follow-up failed to deal with psychological problems which then surfaced later.

Catharsis, at its best, represents a small step in the healing process which needs to be part of an extensive and sustained therapeutic intervention. At its worst, a cathartic experience can represent the unskilled opening of psychic wounds that have closed to some degree, and there is no guarantee that the re-opening will result in needs being met and healing taking place. 
A further criticism of the TRC's claim to have facilitated reconciliation and healing in some cases is that the impact in the greater context that is, of numerous individuals as well as of the collective nation would have been minimal, because only a few people had the opportunity for testimony and the subsequent cathartic experience.

Alfred Allen (2000:199) states that, while many non-professionals accept the myth that catharsis leads to healing, many mental health professionals are sceptical about the TRC as a healing process. This acceptance is dangerous, because survivors may be misled to testify, believing that it will be good for them; governments believing the myth may fail to allocate funds to meet survivors' treatment needs; "such a belief may also deprive people who are in grave need of treatment because their needs are not appreciated", and "there is a risk that those responsible for future legislation and the provision of mental health services ... may fail to provide the necessary resources that will meet the needs of survivors".

\subsection{The TRC: a contributor to the creation of a democratic, human rights culture and a restorative justice ethic}

The TRC contributed to the creation of a democratic, human rights culture, and the shift from a punitive to a restorative justice ethic in South Africa. Its strengths and weaknesses, successes and failures present to all South Africans a call and a challenge to build upon and consolidate that legacy by the promotion of a just criminal justice and judicial system, and economic justice. Justice is a necessary part of reconciliation, but reconciliation is not just about dealing with the past; it is also about the present and the future. The TRC has put on record the need for reparation and economic justice.

In Restorative justice: dealing with the past differently, Charles VillaVincencio (2000b:76) states that in transitional politics, political wisdom has to do with steering the ship of state "between impunity and unrestricted punishment". The challenges of restorative justice "extend beyond prosecution and the courtroom. It includes punitive justice where necessary, while ultimately addressing the covenant the nation has made with itself concerning the values captured in the postscript to the interim Constitution". The TRC was but one answer to the question: "was South Africa going down the road of (retributive) justice or was it seeking reconciliation as it addressed its apartheid legacy?" (De Lange, 2000:23). The options as to whether to go the route of retributive justice or restorative justice were initially - and still are - seen as mutually exclusive, that is, it is one or the 
other - just punishment or forgiveness. It is surely better in both theory and practice, to see not two mutually exclusive philosophies of justice - as represented by the criminal justice system and restorative justice principles - but a need to balance justice and reintegration into society. Such a balance will draw on both approaches, for even (most) advocates of restorative justice recognise and require the role of punitive justice when necessary.

Quoting political philosopher Hannah Arendt, Alex Boraine (2000:439-441) argues for a restorative approach and states that societies can be assisted to overcome the evils in their past and helped to change for the better through forgiveness on the one hand, and promise on the other. This involves

the recognition that full justice is impossible and that unless there is something beyond punishment, there is little hope for restoration and healing of societies which have been deeply wounded by the conflicts of the past. On the other, there is the emphasis on the need for a contract, a new commitment: a promise that the past will not be repeated, that the future will bring democracy, stability and a culture of human rights based on the rule of law.

Boraine refers to the view of many international commentators, academics and politicians that South Africa's TRC "has struck new ground and has given a new dimension to responses to human rights violations"; he hopes that "its approach in dealing with the past and its emphasis on the promise of a new future, will inspire new and creative thinking and action in many parts of the world".

It could be said that the TRC argued for a shift from an ethic of retribution to an ethic of restorative justice; away from punishment to accountability, reparation or compensation; a culture of human rights and responsibilities based on the rule of Law.

Nevertheless, Wilson (2001:25) argues that public opinion surveys have shown a great deal of opposition to granting amnesty, and that "where blame is established the overwhelming majority of those interviewed preferred not forgiveness or amnesty, but punishment and the right to sue through the courts". He further argues that the "TRC was not particularly effective in creating a new culture of human rights or greater respect for the rule of law" (Wilson, 2001:227), and that "as long as human rights institutions function as a substitute for criminal prosecutions they will be resisted by some victims and denounced as a 'sell-out' by informal justice institutions". The TRC he believed, deflected pressure for the more serious 
project of transforming the legal system in order to make it more representative, quick and fair. In his view, the most damaging outcome of truth commissions is that they equate human rights with reconciliation and amnesty.

Villa-Vincencio (2000:76) quoting Howard Zehr, suggests that from a restorative justice perspective, the TRC "is flawed, opportunities have been missed but the importance of this understanding [of justice] - not only in South Africa, but for the world - must not be underestimated". Restorative justice "extends beyond any particular initiative or juridical procedure. It has to do with what President Mandela ... called the 'RDP of the soul' ... what Shimon Perez ... calls 'not a dogma, [but] a civilization, a set of attitudes to peace, justice and equality'”.

This will demand of all South Africans a commitment to a culture of human rights based on democratic structures, the rule of Law, a criminal justice and legal system that is representative, quick and fair, and a commitment to economic justice of which reparation is but a small part.

\subsection{The TRC: a reminder that reconciliation is both a goal and a process}

The TRC has reminded the nation that reconciliation is both a goal and a process. Further, it has warned of the dangers of mistaking one for the other, as well as the inherent dangers of wanting the goal so much as to force the process. It may be helpful to mention one confrontation which serves to illustrate that danger.

Two recurring questions were put to amnesty seekers and victims respectively: Are you sorry? Do you forgive? When confession with apology was offered and received with forgiveness, the Commissioners applauded this as evidence that reconciliation and healing were taking place. Sadly, when these questions were answered negatively, the Commissioners were frequently at a loss as how to respond, other than to express sadness that a contrary spirit had entered into the peaceful process of reconciliation.

A revealing example of this was given during the so-called Winnie Hearings. Bishop Tutu and Ms. Madikizela-Mandela seemed to represent two contrasting - indeed, violently conflicting - black South African responses to the past. On the one hand, Bishop Desmond was the icon of Christian forgiveness and reconciliation; on the other, Winnie was the "Mugger of the Nation", unrepentant, 
unforgiving and angry, saying no to both questions - for she was both perpetrator and victim. Desmond's voice was that of a good shepherd, the blessed peacemaker, forgiving his enemies as he had been forgiven. Winnie's was the voice of black vengeance, of repressed emotions and smouldering discontent, of the economically disempowered (despite her contrary lifestyle of indulgence and extravagance), the victim of oppression and violence who was herself out of control.

Madikizela-Mandela became the symbol of a historical disjunctive, the ANC's own break with the past, the excesses of the 1980s struggle, and the new national historicity. In contrast, Desmond Tutu was elevated as a symbol of reconciliation and the continuity between humanitarian motives in the past and the present (Wilson, 2001:165).

Tutu's impassioned pleas to Madikizela-Mandela, along with his declaration of love and admiration, came under heavy fire. Speaking more as a pastor than a secular commissioner, he probably believed that he could elicit from her "some apology, some acceptance of responsibility, some accountability. Such a response was not really forthcoming" (Boraine, 2000:253). At most, she was prepared to concede that "things went horribly wrong".

Despite her vilification, Madikizela-Mandela continues to be the national voice of black vengeance, someone who articulates widespread emotions of anger at the continued racialisation of privilege in the new South Africa, and the lack of economic betterment for the majority of black South Africans.

Her ability to channel and articulate this resentment is the best explanation for her continued popularity ... Winnie MadikizelaMandela is still the national figure articulating a perspective that keeps alive the aspirations of a liberation narrative of the 1980s ... She rejects reconciliation and instead nurtures the desire for a Robert Mugabe-style seizure of the political and economic resources still held by a white elite (Wilson, 2001:165).

One of Tutu's critics, Gwynne Dyer, a London based independent journalist and historian, believed that he should have discredited Madikizela-Mandela when he had the chance; "he wrote in very strong language, 'The monster is still on the loose and South Africa will pay the price for years"' (Boraine, 2000:253). But surely to silence and repress dissonant voices, and to marginalise those who raise them, is to ensure that things will go horribly wrong again and again for many, many years! 
Following the Winnie Hearings and the publication of the TRC report, the ANC's publication of its election list, "in which Winnie Madikizela-Mandela was placed in the top ten, is an indication perhaps, of how the ANC views the TRC's findings" (Orr, 2000:323) - or perhaps an indication that someone in power recognises that freedom, like reconciliation, is both a goal and a process!

\section{Reconciliation: according to the TRC}

The Commissioners' task was aggravated by at least two problems: firstly, the term reconciliation was not defined "and its meanings proliferated and transformed during the life of the Commission" (Wilson, 2001:98); secondly, the subjects of reconciliation, who was to be reconciled to whom, were not specified other than "the people of South Africa". Nevertheless, Wilson has identified three main narratives of reconciliation that emerged during the Commission. These are: the legal-procedural; the mandarin-intellectual; and the religious-redemptive.

The legal-procedural closest to the Act, and dominant among the TRC lawyers and Amnesty Committee members (mostly judges), was concerned with applications of amnesty in exchange for disclosure. Not concerned with imposing values, political judgements, seeking evidence of remorse or repentance, the focus was on meeting the required criteria. Within this narrative, reconciliation could be compared to a medieval penitent seeking indulgences when the applicant brings a full disclosure, he/she indemnified springs from prosecution! Is there not a challenge here for Reformed theologians?

The mandarin-intellectual narrative, dominant among members of the Human Rights Violation Committee (HRVC), which provided the most intellectual leadership of the three committees, and the Research Unit, was not prevalent at the level of TRC practice. Reconciliation here meant "reconciling the non-racial, constitutionally defined nation of the present with the racially exclusive nation of the past". Rejecting an individually-orientated view of reconciliation in favour of a more global (abstract) view, the question as to who is responsible for victim-offender mediation remains unanswered.

In contrast to the proceduralist assumptions of the two prior paradigms, the religious-redemptive narrative pursued a substantive notion of reconciliation as a common good, defined by confession, forgiveness and redemption, and the exclusion of vengeance (Wilson, 2001:109). This view of reconciliation was advocated most 
strongly by Desmond Tutu and members of the Reparations and Rehabilitation Committee (many of whom were health care professionals). In Wilson's view, the lack of any mass TRCsponsored program of mediation, as well as "the absence of secular and political mechanisms to deal with and properly resolve conflict", meant that the Human Rights Violations' (HRV) "hearings became a symbolic substitute".

Wilson (2001:121) claims it was Desmond Tutu more than any other national figure, and largely due to his personal force and charisma, who:

... was able to combine three key narratives in his public statements - Christian morality, the liberation narrative of the 1980 s and the reconciliation narrative of the 1990s. Due to his influence, the TRC initially made substantial promises to reconcile individuals and social groups.

This was so in part, because the other versions - the legal and the intellectual - "were too abstract, cerebral and bloodless, to create a new hegemony within the media and to appeal to most South Africans" (Wilson, 2001:122).

The conjoining of TRC and individual narratives of suffering - as well as the cathartic power of story telling - led to a new narrative, a new story, a new truth, and a new future. "The liberation narrative focussed on individuals and wrote them into the wider story of liberation of the nation. This is where the TRC was to be most effective in the conversion (replete with its religious connotations) of the individual to a nation - building project" (Wilson, 2001:110).

Wilson (2001:111-121) identifies these stages as follows: recognising and collectivising suffering; the moral equalising of suffering; liberation and sacrifice; and redemption through forsaking revenge.

In the first stage individual testimonies were heard with the Commissioners expressing appreciation for the evidence, sympathy for the witness, and granting value to the testimony. Desmond Tutu's response (23 September 1996) was typical of this process of recognising and collectivising suffering: "Your pain is our pain. We were tortured, we were harassed, we suffered, we were oppressed." Drawing together Christian and psychotherapeutic approaches to suffering - which seek to transcend individuals' preoccupation with their own pain 
individual suffering, which ultimately is unique, was brought into a public space where it could be collectivized and shared by all, and merged into a wider narrative of national redemption. At ritualized HRV hearings, suffering was lifted out of the mundane world of individuals and their profane everyday pain, and was made sacred by attaching these experiences to a sacred image of the nation (Wilson, 2001:121).

While Commissioners tended to assert that all pain was equal, the reaction of partisan audiences - who cheered ANC testimonies, but jeered NP and IFP testimonies - represent a resistance to "such historical revisionism in order to depoliticize the past - this is usually what is meant by 'laying the past to rest'”. Clearly they made a distinction between the actions of those who sought to overthrow an unjust system - a just war - and those who sought to maintain it.

In the next stage there was a shift from the supposed neutrality of the moral equalising of suffering "in order to embrace the just war thesis, to place suffering into the context of the liberation struggle and to grant meaning to trauma and loss". This conjoining of individual, political and religious narratives created a new narrative: "meaning was attached to death by a process of teleologizing - of mapping onto the experiences of the dead and the survivors (of) a narrative of destiny which portrays an inexorable progression towards liberation" (Wilson, 2001:114-15; emphasis added - SB). This, a common feature of survivor's syndrome has been documented for the Holocaust by Bettelheim (1952) and Argentina by Suarez-Orozco (1991).

In this narrative of destiny, suffering was seen not to have been in vain, but for the cause of freedom; those who had, or were still suffering, were not victims, but heroes in the struggle. Thus the past was given redemptive meaning in terms of the future. Conjoined narratives also called for conjoined iconographies, thus, Steve Biko (in The Guardian, 31 March 1998) emerged as the black Christ of the African nation, as well as an Ernesto "Che" Guevara figure, a secular saint of the oppressed. He "symbolises the unfulfilled expectations of the 1970s and is untarnished by the excesses of the 1980 s and the disappointments of the 1990s" (Wilson, 2001:115). Further, each mother who testified became a "mother of the nation", a title previously reserved for those such as Winnie MadikizelaMandela; each mother whose soul had been pierced by sorrow and the sacrifice of her son, or sons, could now look forward to the redemption - if not of Jerusalem, at least - of South Africa. 
"'Sacrifice' provided the main symbolism for grafting individual pain onto wider narratives" (Wilson, 2001:117); and was used whether it was relevant and appropriate or not. Occasionally, it was employed by Commissioners even if the victim rejected a political role, and was unwilling to locate their own suffering in a wider liberation context.

On the first day of the hearings in the Eastern Cape, Desmond Tutu stated: "Forgiveness will follow confession and healing will happen, and so contribute to national unity and reconciliation" (Wilson, 2001:119). Here is evident the structure of predictable, progressive stages, and the dynamic from the individual victim to the collective, and back to the individual, who was urged to respond to confession with forgiveness in order to experience personal healing, "and so contribute to national unity and reconciliation".

What was the TRC's response to those who rejected their narrative and the glorification of suffering as sacrifice for the struggle? What was the Commission's response to those who gave a negative answer to the frequently repeated question: Do you forgive the offender?

Whereas those who relinquished the desire for vengeance were praised, those who expressed "emotions of vengeance, hatred and bitterness were rendered unacceptable, an ugly intrusion on a peaceful, healing process. When such emotions did inevitably emerge at hearings, Commissioners were poorly prepared to deal with them" (Wilson, 2001:120), and preferred to give to hearings that followed the predictable, progressive stages - a nearmiraculous capacity to heal and transform. In making forgiveness a duty incumbent upon victims and marginalising those who refused to accept this responsibility "to contribute to national unity and reconciliation", were the Commissioners not guilty of over-simplifying the complex process, not to mention the theological dynamics at work? Worse still, were they not sometimes guilty of abuse themselves?

Given that the religious-redemptive narrative, "the only one with any purchase in society", tended to dominate, though resisted by some, how does it compare to or contrast with a Christian understanding of reconciliation? 


\section{Reconciliation: a Christian understanding}

A Christian definition of reconciliation, suggests Roman Catholic Priest, Mark Hay (1998:105), needs to include specific assumptions of a theological anthropology; that is, it will need to attend to its presuppositions about God, the human person and the community, for only in relation to God and others can the individual be properly understood.

At the heart of the Christian message is the conviction that God is holy, just, righteous, loving, compassionate, merciful and gracious on the one hand, and that humankind is fallen, separated and alienated from God, unable to restore the break, on the other. For the break to be closed and for God and humankind to be made one again or reconciled, God must take the initiative. This God begins to do by a series of covenants - contractual relationships - whereby humanity is called to God. All covenants are precursors of that made in Jesus Christ; in this new covenant God identified with humanity by becoming human: "The Word became flesh and made his dwelling among us" (John 1:14a). On the cross he reconciled us to himself through Christ and gave us the ministry of reconciliation: that God was reconciling the world to himself in Christ, not counting" our sins against us, and "has committed to us the message of reconciliation" (2 Cor. 5:18, 19a; 5:19b).

Theories of the atonement abound in attempts to explain theologically how God does this, but at the heart of all of these, is the conviction that in Jesus Christ, truly divine and truly human, God has reconciled the demands of divine justice and divine love. God does this by becoming vulnerable and paying the price. The heavenly vision of Jesus is that of "a lamb, looking as if it had been slain, standing in the centre of the throne", the lamb who with his "blood ... purchased men [and women] for God from every tribe and language ... [and has] made them to be a kingdom and priest to serve our God, and they shall reign on the earth" (Rev. 5:6a, 9b, 10). The response is less to understand - though certainly to try to understand and to communicate that doctrinal understanding - than it is to worship: "Worthy is the lamb, who was slain, to receive power and wealth and wisdom and strength and honour and glory and praise!"

To the reconciled, God has committed the message and the ministry of reconciliation, the subjects of which are God, the human person, and the human community. This reconciliation is not just a goal and a process; it is an intentional goal and process. In Christian terms it 
involves metanoia, repentance, a turning away from and a turning towards. It may also include reparation or restitution. Indeed, it may also include living with the consequences of one's choices, but this redemptively.

Reconciliation may, therefore, be between God and the individual, or between individuals and individuals, or between groups and groups. However, reconciliation in its social context is defined, it is not likely to be an exhaustive or exclusive definition. Each context is different and, because of that, may require different ritual elements in the dynamics of reconstruction. It is better therefore, to speak of the dynamics rather than of the models - or even processes - of social reconciliation, for there can hardly be one prescriptive model involving a predictable, linear sequence.

\section{Reconciliation: dynamics of social reconciliation}

What are the dynamics of social reconciliation? What needs to happen for a victim and an offender to arrive at reconciliation? What about the unrepentant, those who refuse or do not see the need to say: "I am sorry, please forgive me"? Where do bystanders and/or the wider community fit in? How do we know when reconciliation has been achieved?

To help understand some of the dynamics of social reconciliation, and to attempt an answer to these questions, Hay draws on two sources, one ecclesial - the order of penitents from the early centuries of the Christian church - and one anthropological - the concept of social drama - and identifies certain similarities between them. Both models indicate that some process needs to be facilitated in order for reconciliation to be effected. Reconciliation doesn't just happen, steps need to be taken; the process needs to be uncomplicated and manageable for both the individuals involved and the community; and the community has a role to play as healer, as has its representative leaders.

Among the steps needed, the following can be identified as necessary:

- confronting and naming the breach - confession;

- taking redressive action, which may include the use of:

- dialogue, including story telling,

- intermediaries, 
- rituals;

- changing values and behaviour - repentance;

- making reparation;

- attending to the past, but focussing on the future;

- communicating, communicating and communicating - the ongoing dynamic of transparency and accountability cannot be overestimated;

- celebrating;

- involving the whole community - "For healing and lasting reconciliation to happen the community needs to be involved" (Hay, 1998:113).

Mark Hay (1998:121-22) concludes that social reconciliation includes the individual and the community, "where the psyche and memory ... need to be healed through the recovery of human dignity and honour, repairing relationships, meeting the demands of justice and reparation, along with a renewed appreciation and exercising of a culture of human rights ... The Christian message of reconciliation challenges us to move beyond", an often utilitarian and justiceorientated approach to a Spirituality of reconciliation, which is more than a strategy, "while remaining concrete and practical".

\section{Conclusion}

Given its mandate - to promote, not to achieve reconciliation - did the TRC promote reconciliation at a national level, and between amnesty seekers and victims? In fairness the answer to that question must be yes and no. Yes, the Commission' process allowed for the exchange of information, the expression of emotions, the admission of guilt, apology, the granting of forgiveness, reconciliation, restitution and healing in some cases. No, and this in spite of Section $11(\mathrm{~g})$ of the Act which made provision for "informal mechanisms for the resolution of disputes, including mediation ... where appropriate, to facilitate reconciliation and redress for victims". A further stage in the TRC could - should? - have been mechanisms "in which the amnesty seeker could have compensated the victim, if this appeared to be appropriate. This process would not only have brought the truth to the surface, but would also have improved the probability of individual reconciliation between victims and amnesty seekers. This might also have contributed to reconciliation at national level" (Allen, 2001:197). One reason for the 
Commission's failure was that - with some exceptions - it generally failed to facilitate the process between victims and amnesty seekers, and this, because it tended to limit their respective roles to that of witnesses rather than to make them more active participants in the process.

Certainly, the TRC can be, and has been criticised from many perspectives, but it deserves to be evaluated in these terms: Did the South African Truth and Reconciliation Commission:

- confront and name the gross human rights violations of the past?;

- attend to the past, both in its individual and collective dimensions, yet focus on the future, both in its individual and collective dimensions?;

- provide space for stories to be told and for catharsis?;

- reconciliation and healing to happen?;

- recommend adequate reparation?;

- communicate its findings?;

- result in new perspectives, understanding, values, priorities, behaviour and goals?; and

- promote a human rights culture and a commitment to ensure that the past is not repeated?

Perhaps it is only fair to allow both the vice-chairperson and the chairperson of the Commission to speak. Alex Boraine (2000:295296) maintains that:

The search for reconciliation and restoration is in my mind an integral part of coming to terms with the past. It is not enough simply to punish perpetrators. Not only is broader reconciliation and restoration necessary and morally right, but it places the focus not so much on the past but on the present and the future. We come to terms with the past not to point a finger or engage in a witch hunt but to bring about accountability and to try to restore a community which for scores of years has been broken. The South African Truth and Reconciliation Commission unashamedly sought to advance the process of reconciliation ... bringing the perpetrator back into society, and helping to restore to victim and perpetrator the dignity which both have lost. In this regard ... [the TRC] ... was not 'second best'. 
"What about reconciliation?" asks Bishop Desmond Tutu (1998:5) and then answers:

Many people have an erroneous understanding of reconciliation. They say the TRC is unpopular and has tended to exacerbate sectional feelings. It is because they want a cheap reconciliation with no confrontation. They have forgotten that the Son of God who came to effect reconciliation was killed for his pains to show that reconciliation is not easy or cheap. They have forgotten that this Jesus ... was always causing division, causing a crisis, making people chose, saying ... that He had brought a sword. And even so the TRC can point to some extraordinary moments when reconciliation has happened (emphasis added - SB).

From a Christian perspective, reconciliation is not only a goal and a process, and intentional ones at that, but something that is already done for us, yet done in, through, and with us. It involves the Biblical principles of responsibility, confession, repentance, forgiveness, reparation or restoration where possible, and reconciliation. In many cases it may mean some form of accountability if trust is to be restored, or established for the first time. It may mean having to live - but to live redemptively - with the consequences of one's choices; it will certainly involve a change of attitude and behaviour. Conflict resolution, mediation and reconciliation are dynamic processes and may include the following stages: a primary stage where disputants are encouraged to explain their behaviour and to express their emotions; a further stage may be in accepting personal responsibility, either of culpability, or of how one chooses to integrate the past with the present, whether retribution or forgiveness; a final stage may be to facilitate a mutually negotiated and agreed settlement often involving changed behaviour on one, both, or all sides. A restorative justice approach would see this as involving the offender, the victim, and the community. A Christian approach to reconciliation and restoration would see the necessity of four roleplayers in that process, namely God, the offender, the offended, and the community.

At the conclusion of the TRC its chairperson, Archbishop Desmond Tutu, gave a reminder that the purpose of the Commission was to promote, not to achieve reconciliation. That task, he maintained, has to be the responsibility of all South Africans, and expressed the hope that the Christian churches would be in the forefront of this process. With all its faults, limitations and unfinished business, the TRC can be said to have promoted reconciliation and the building of 
a democratic human rights and restorative justice culture, based on the rule of law. Further, it has reminded the Christian community, both of its own need for reconciliation, and issued a call and challenge to it to be ministers - indeed a message of reconciliation.

All this is from God, who reconciled us to himself through Christ and gave us the ministry of reconciliation: that God was reconciling the world to himself in Christ, not counting [humanity's] sins against them. And he has committed to us the message of reconciliation (2 Cor. 5:18, 19).

May the God of peace [equip us] with everything good for doing his will, and may He work in us what is pleasing to Him through Jesus Christ, to whom be glory forever and ever. Amen (Heb. 13:20).

\section{List of references}

ALLEN, ALFRED. 2000. Truth and reconciliation: a psycholegal perspective. Ethnicity \& Health, 5(3/4):191-204.

BORAINE, ALEX. 2000. A country unmasked: inside South Africa's Truth and Reconciliation Commission. Oxford: Oxford University Press.

DE LANGE, JOHNNY. 2000. The historical context, legal origins and philosophical foundations of the South African Truth and Reconciliation Commission. (In Villa-Vincencio, Charles \& Verwoerd, Wilhelm, eds. Looking back reaching forward: reflections on the Truth and Reconciliation Commission of South Africa. Cape Town: UCT Press. p. 14-31.)

FOSTER, DON. 2000. What makes a perpetrator? An attempt to understand. (In Villa-Vincencio, Charles \& Verwoerd, Wilhelm, eds. Looking back reaching forward: reflections on the Truth and Reconciliation Commission of South Africa. Cape Town: UCT Press. p. 219-238.)

HAY, MARK, (OMI). 1998. Ukubuyisana: reconciliation in South Africa. Pietermaritzburg: Cluster.

ORR, WENDY. 2000. Reparation delayed is healing retarded. (In Orr, Wendy. From Biko to Basson. Saxonwold: Contra. p. 323.)

THE HOLY BIBLE. 1999. New international version. Cape Town: Bible Society of South Africa.

TUTU, DESMOND. 1998. The Truth and Reconciliation Commission. (In Du Toit, C.W., ed. Confession and reconciliation. Pretoria: Research Unit for Theology and Religion, UNISA. p. 4-6.)

VILLA-VINCENCIO, CHARLES. 2000a. Getting on with life: a move towards reconciliation. (In Villa-Vincencio, Charles \& Verwoerd, Wilhelm, eds. Looking back reaching forward: reflections on The Truth and Reconciliation Commission of South Africa. Cape Town: UCT Press. p. 199-209.)

VILLA-VINCENCIO, CHARLES. 2000b. Restorative justice: dealing with the past. (In Villa-Vincencio, Charles \& Verwoerd, Wilhelm, eds. Looking back reaching forward: reflections on the Truth and Reconciliation Commission of South Africa. Cape Town: UCT Press. p. 68-76.) 
WILSON, RICHARD A. 2001. The politics of truth and reconciliation in South Africa, legitimizing the post-apartheid state. Cambridge: CU Press.

\section{Key concepts:}

human rights violations

reconciliation: a Christian definition

reconciliation: according to the TRC

retributive vs restorative justice?

Truth and Reconciliation commissions

\section{Kernbegrippe:}

menseregteskendings

rekonsiliasie: 'n Christelike definisie

rekonsiliasie: volgens die WVK

strafregtelike vs herstellende wetgewing

Waarheids- en Versoeningskommisies 